point is in the State of Nevada in the Walker Lake region, and is close to the epicentre of the earthquake of June 25, 1933, and about 50 miles west of that of the great earthquake of December 21, 1932, one of the most violent recorded in the United States (Wire Report, Science Service, Washington, D.C., January 30 and 31 ).

\section{Pyrex Glass for the 200 in. Reflector}

According to a Science Service report, the $200 \mathrm{in}$. mirror of the new Califormian telescope will be made of a sort of pyrex glass and will be poured very shortly. It was at one time proposed to make the mirror of fused quartz, but a superior pyrex glass, which has a small temperature coefficient of expansion, has been developed for the purpose. The glass will be taken from the furnace at a temperature of $1,500^{\circ} \mathrm{C}$. and poured at about $1,000^{\circ} \mathrm{C}$. The cooling and annealing processes will occupy several months. The oven for the large reflector has already been used to make a 120 in. flat which will be required to test the larger mirror. Preliminary tests for strain have shown that this flat is superior to the excellent 60 in. mirror now used at Mount Wilson. The flat is perfectly clear and almost free from bubbles. The test flat will have the same type of construction as the big mirror, namely, a hexagonal system of ribs, which gives rigidity, and in which nineteen points of support will be provided. Ten supporting levers will be attached in ball bearings so that frictional and elastic distortions will be minimised. The holders will work in any position so that the mirrors can hang upside down if necessary.

\section{Work of International Polar Year Expedition}

THE Symons memorial lecture of the Royal Meteorological Society will be given on Wednesday, March 21, at 7.30 p.m., by Mr. J. M. Stagg, leader of the British Expedition which occupied Fort Rae in Canada during the Second International Polar Year, 1932-33. The site of Fort Rae is of exceptional interest, as it lies near the zone of maximum frequency of aurora, and auroral photography was one of the most important objects of the expedition. Extensive studies were also made in meteorology, including upper air investigation, atmospheric electricity and terrestrial magnetism. The expedition occupied a site very near to that of the Canadian and British expedition during the first International Polar Year of 1882-83, and this gave an opportunity for obtaining valuable determinations of secular change of the magnetic elements. Mr. Stagg will also describe some of the practical difficulties and interesting or unusual experiences which the expedition met with. As the lecture this year is of unusual interest, the Council has obtained the use of the hall of the Rcyal Geographical Society, Kensington Gore. An additional meeting of the Royal Meteorological Society will be held on March 28 , at 5.30 p.m., at 49 Cromwell Road, South Kensington, when Prof. W. Schmidt, Director of the Central Meteorological Institute, Vienna, will deliver a lecture on micro-climatological work in Austria.

\section{Announcements}

Dr. Harlow Shapley, director of Harvard College Observatory and Paine professor of astronomy at Harvard University, will deliver the George Darwin lecture for 1934 at the ordinary meeting of the Royal Astronomical Society on May 11, taking as his subject "Some Structural Features of the Metagalaxy".

Ax the annual general meeting of the Society of Public Analysts held on March 2, the following officers were elected for the year 1934 :-President, Mr. John Evans; Vice-Presidents, Messrs. L. Eynon, S. E. Melling, A. More, W.H. Roberts ; Honorary Treasurer, Mr. E. B. Hughes; Honorary Secretary, Mr. G. Roche Lynch.

At the annual general meeting of the Geological Society of London on February 16, the following officers were elected : President, Mr. J. F. N. Green; Vice-Presidents, Prof. P. G. H. Boswell, Prof. W. S. Boulton, Sir Thomas Holland and Mr. W. Campbell Smith; Secretaries, Prof. W. T. Gordon and Dr. L. Hawkes ; Foreign Secretary, Sir Arthur Smith Woodward; Treasurer, Mr. F. N. Asheroft.

A conference on "Modern Changes in the Treatment of Light Soils" has been arranged to be held at Rothamsted Experimental Station on March 20, at 11.30. Further information can be obtained from the Secretary, Rothamsted Experimental Station, Harpenden.

THE Faraday Society has arranged a general discussion on "The Determination and Interpretation of Dipole Moments" to be held at Exeter College, Oxford, on April 12-14, under the presidency of Dr. N. V. Sidgwick. The discussion, which will be introduced by Prof. P. Debye (Leipzig), will be divided into two parts, namely, determination and interpretation. Among the foreign visitors who have promised papers are: Dr. A. E. van Arkel (Eindhoven), Dr. J. L. Snoek (Eindhoven), Dr. E. Bretscher (Zurich), Prof. P. Girard (Paris), Dr. O. Hassel (Oslo), Prof. F. Horst Müller (Leipzig), Prof. W. H. Rodebush (Illinois), Prof. C. P. Smyth (Princeton), and Prof. J. W. Williams (Wisconsin). Further information can be obtained from the Secretary, Faraday Society, 13 South Square, Gray's Inn, London, W.C.1.

Applications are invited for the following appoint. ments, on or before the dates mentioned :-Temporary civil engineering assistants for the London County Council-The Chief Engineer (D), County Hall, Westminster Bridge, S.E.1 (March 20). A head of the Department of Mathematics and Physics at the Municipal Technical College, Halifax-The Education Officer, Education Offices, West House, Halifax (March 23). Borough electrical engineer and manager, County Borough of Halifax-Town Clerk, Town Hall, Halifax (March 24). A demonstrator in inorganic and physical chemistry, Bedford College for Women - Secretary (April 21). A head of the Department of Building at Heriot-Watt College, Edinburgh--The Principal (April 23). A lecturer in chemistry, University of Reading-Registrar (May 7). 